\title{
Design Considerations for Connecting Rod
}

\section{B. Sriharsha, P. Sudhakar Rao}

\begin{abstract}
Connecting rod is one of the engine's key components which connect the piston to the crankshaft and converts the piston's reciprocating motion into the crankshaft's rotation. Connecting rod must be sufficiently strong to withstand the thrust from the piston during the combustion process. During its lifespan, it faces a lot of tensile and compressive loads. The objective of this paper is to modify the connecting rod design and changing the material of connecting rod for weight reduction possibilities. Model of the connecting rod is designed with the help of INVENTOR and analysis was performed by using ANSYS.
\end{abstract}

Keywords: ANSYS, Connecting rod, INVENTOR, Piston.

\section{INTRODUCTION}

Connecting rod is one of the engine's key components which connect the piston to the crankshaft and converts the piston's reciprocating motion into the crankshaft's rotation [1]. Connecting rod must be sufficiently strong to withstand the thrust from the piston during the combustion process [1]. During its lifespan, it faces a lot of tensile and compressive loads. Connecting rod consists of small end, shank and big end [4]. The piston is connected to the small end of the connecting rod by gudgeon pin or wrist pin and the big end of connecting rod connects to the crankpin on the crank shaft [4]. Big end of some connecting rods split into two halves so that it can be clamped around the crank journal. The connecting rod's shank can have different cross sections such as circular section, I- section, $\mathrm{H}$ - section and rectangular section [4].With minimum weight, the connecting rod should have sufficient strength [11].Steel and aluminum are the materials most widely used to produce the connecting rod [13]. Certain materials, such as titanium alloy, magnesium alloy and beryllium, were also used in the fabrication of the connecting rod. Gas pressure causes compressive stresses and inertia causes tensile stresses in it. Gas pressure is responsible for the maximum force on connecting rod [19].

Forces acting on connecting rod are [19]

1. Force on piston due to gas pressure and inertia of reciprocating parts.

2. Force due to inertia of the connecting rod.

3. Force due to friction of the piston and piston rings.

4. Force due to friction of the piston pin and crank pin bearings

Design of connecting rod depends upon the speed of the engine. High speed engines uses connecting rod of I-Section and low speed engines uses connecting rod circular cross section [20].

Revised Manuscript Received on February 05, 2020.

* Correspondence Author

B. Sriharsha, pursuing Master of Engineering (Manufacturing Technology) from NITTTR, Chandigarh.

Dr. P. Sudhakar Rao, Assistant Professor in Mechanical Engineering Department, NITTTR, Chandigarh.

(C) The Authors. Published by Blue Eyes Intelligence Engineering and Sciences Publication (BEIESP). This is an open access article under the CC BY-NC-ND license (http://creativecommons.org/licenses/by-nc-nd/4.0/)
Casting, forging and powder metallurgy are manufacturing processes for the connecting rods. Material used to fabricate the connecting rod depends on the engine. In industrial engines medium carbon steel is used for making connecting rods. Automobile engines uses alloy steel connecting rods [28]. Reducing the weight of the connecting rod is one way to reduce the inertia forces on a connecting rod for that we can use aluminum material. Bending and axial stresses are induced in the connecting rod during engine operation.

Fatigue, pin failure, over revving, less lubrication, hydrostatic lock causes the failure of a connecting rod.

\section{LITERATURE REVIEW}


Design Considerations for Connecting Rod

Table- I: Literature Review

\begin{tabular}{|c|c|c|c|c|c|}
\hline S.No. & Ref. No. & Authors & Objectives & Softwares & Conclusions \\
\hline 1 & {$[1]$} & Vinayak et al. & $\begin{array}{l}\text { In this study authors } \\
\text { analyzed the connecting } \\
\text { rod with different materials } \\
\text { and compared the results. }\end{array}$ & $\begin{array}{l}\text { - } \quad \begin{array}{l}\text { The 3D connecting } \\
\text { rod model was } \\
\text { created with NX 6.0. }\end{array} \\
\text { - } \begin{array}{l}\text { ANSYS } 14.5 \text { was } \\
\text { used to perform static } \\
\text { structural analysis. }\end{array}\end{array}$ & $\begin{array}{l}\text { Weight reduction in the } \\
\text { connecting rod was observed } \\
\text { in the optimized design } \\
\text { where they modified the } \\
\text { connecting rod dimensions } \\
\text { without altering the main } \\
\text { dimensions. }\end{array}$ \\
\hline 2 & {$[2]$} & Nilam et al. & $\begin{array}{l}\text { To suggest weight } \\
\text { reduction opportunity for } \\
\text { connecting rod by } \\
\text { analysing it with different } \\
\text { materials. }\end{array}$ & $\begin{array}{l}\begin{array}{l}\text { The 3D connecting } \\
\text { rod model was } \\
\text { created with CATIA. }\end{array} \\
\text { - Analysis was } \\
\text { conducted using } \\
\text { ANSYS. }\end{array}$ & $\begin{array}{l}\text { - } \\
\text { Authors concluded that } \\
\text { connecting rod weight } \\
\text { reduction can be } \\
\text { accomplished through the } \\
\text { use of composite materials } \\
\text { such as carbon fiber. }\end{array}$ \\
\hline 3 & [3] & Adnan et al. & $\begin{array}{l}\text { Computation of strength } \\
\text { and deformation } \\
\text { characteristics of } \\
\text { connecting rod. }\end{array}$ & 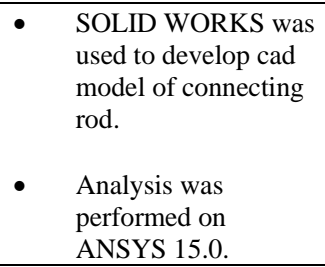 & $\begin{array}{l}\text { - } \quad \text { Authors suggested Titanium } \\
\text { alloy for manufacturing of } \\
\text { connecting rod. }\end{array}$ \\
\hline 4 & [4] & Vikas et al. & $\begin{array}{l}\text { To determine best material } \\
\text { for connecting rod. }\end{array}$ & $\begin{array}{ll}\text { - } & \text { Using SOLID } \\
\text { WORKS - 2016, } \\
\text { connecting rod model } \\
\text { was developed. } \\
\text { - } \quad \text { Analysis was } \\
\text { conducted using } \\
\text { ANSYS 16.2. }\end{array}$ & $\begin{array}{l}\text { - Authors concluded that from } \\
\text { portions where stress is } \\
\text { minimal, material can be } \\
\text { curtailed. } \\
\text { - Suggested beryllium alloy } \\
\text { for production of connecting } \\
\text { rod. }\end{array}$ \\
\hline 5 & [5] & $\begin{array}{l}\text { Magesh } \\
\text { Kumar and } \\
\text { Ankush } \\
\text { Biradar }\end{array}$ & $\begin{array}{l}\text { To optimize the weight of } \\
\text { steel connecting rod. }\end{array}$ & $\begin{array}{l}\text { UG NX 7.0 was used } \\
\text { to build the } \\
\text { connecting rod cad } \\
\text { model. } \\
\text { - Analysis was } \\
\text { performed on } \\
\text { ANSYS 15.0. }\end{array}$ & $\begin{array}{l}\text { - Use of composite materials } \\
\text { reduces the weight of } \\
\text { component. }\end{array}$ \\
\hline 6 & {$[6]$} & $\begin{array}{l}\text { Dipalee } \\
\text { Bedse }\end{array}$ & $\begin{array}{l}\text { Design evaluation with the } \\
\text { help of FEA for fatigue life } \\
\text { of connecting rod. }\end{array}$ & $\begin{array}{ll}\text { - } & \begin{array}{l}\text { Connecting rod } \\
\text { model has been } \\
\text { developed using } \\
\text { CATIA. }\end{array} \\
\text { - } & \text { FEA was done by } \\
\text { using HYPER MESH } \\
\text { and FEMFAT. }\end{array}$ & $\begin{array}{l}\text { - } \\
\text { Minor changes in the } \\
\text { connecting rod geometry like } \\
\text { increasing neck radius, etc., } \\
\text { improves the connecting } \\
\text { rod's fatigue life. }\end{array}$ \\
\hline 7 & [7] & $\begin{array}{l}\text { Ganta } \\
\text { Krishnarjuna } \\
\text { Reddy and } \\
\text { Badde Naik }\end{array}$ & $\begin{array}{l}\text { Static structural analysis of } \\
\text { connecting rod of various } \\
\text { materials. }\end{array}$ & $\begin{array}{ll} & \text { SOLID WORKS } \\
& 2016 \text { was used to } \\
\text { develop connecting } \\
\text { rod model. } \\
\text { - } \\
\text { Static structural } \\
\text { analysis for various } \\
\text { materials was } \\
\text { performed on } \\
\text { ANSYS 14.5. } \\
\end{array}$ & $\begin{array}{l}\text { Materials with low stress } \\
\text { values are preferable for the } \\
\text { production of connecting } \\
\text { rod. }\end{array}$ \\
\hline 8 & {$[8]$} & $\begin{array}{l}\text { Wankhade } \\
\text { and Suchita } \\
\text { Ingale }\end{array}$ & $\begin{array}{l}\text { To determine the best } \\
\text { material that can be used } \\
\text { for manufacturing of } \\
\text { connecting rod. }\end{array}$ & 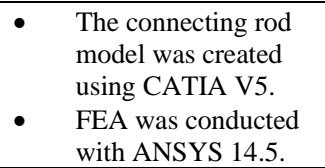 & $\begin{array}{l}\text { Authors suggested Carbon } \\
\text { fiber material for connecting } \\
\text { rod of diesel engine. }\end{array}$ \\
\hline 9 & [9] & Nilam et al. & $\begin{array}{l}\text { It is a review paper about } \\
\text { connecting rod design } \\
\text { analysis for weight } \\
\text { reduction. }\end{array}$ & • $\quad$ Review paper & $\begin{array}{l}\text { - Authors concluded that there } \\
\text { is a scope to try other } \\
\text { materials than forged steel } \\
\text { for manufacturing } \\
\text { connecting rods. }\end{array}$ \\
\hline 10 & [10] & $\begin{array}{l}\text { Mansi } \\
\text { Satbhai and } \\
\text { Talmale }\end{array}$ & $\begin{array}{l}\text { It is a review paper } \\
\text { associated with design and } \\
\text { analysis of connecting rod. }\end{array}$ & - $\quad$ Review paper & $\begin{array}{l}\text { - } \quad \text { Authors framed a } \\
\text { methodology for designing a } \\
\text { connecting rod. }\end{array}$ \\
\hline
\end{tabular}




\begin{tabular}{|c|c|c|c|c|c|}
\hline 11 & [11] & $\begin{array}{l}\text { SatishWable } \\
\text { and Dattatray } \\
\text { S. Galhe }\end{array}$ & $\begin{array}{l}\text { The main objective of this } \\
\text { study is to optimize the } \\
\text { weight of connecting rod. }\end{array}$ & $\begin{array}{ll}\text { CATIA has been } \\
\text { used to build } \\
\text { connecting rod } \\
\text { model. } \\
\text { Analysis was } \\
\text { performed on } \\
\text { ANSYS 14. } \\
\end{array}$ & $\begin{array}{l}\text { Aluminium MMC } \\
\text { connecting rod is light in } \\
\text { weight and showing less } \\
\text { stress than current carbon } \\
\text { steel connecting rod for } \\
\text { weight optimization. }\end{array}$ \\
\hline 12 & [12] & $\begin{array}{l}\text { Harshit } \\
\text { Mishra and } \\
\text { prof. Kuldeep } \\
\text { Narwat }\end{array}$ & $\begin{array}{l}\text { The main objective of this } \\
\text { paper is to perform static } \\
\text { and modal analysis of } \\
\text { connecting rod. }\end{array}$ & $\begin{array}{ll}\text { - } & \text { By using SOLID } \\
\text { WORKS 2014, solid } \\
\text { modeling of the } \\
\text { connecting rod was } \\
\text { built. } \\
\text { - Analysis was } \\
\text { conducted using } \\
\text { ANSYS 14.5. }\end{array}$ & $\begin{array}{l}\text { Connecting rod model was } \\
\text { safe during structural } \\
\text { analysis by providing factor } \\
\text { of safety value more than } 1 \\
\text { for all the analyzed } \\
\text { materials. }\end{array}$ \\
\hline 13 & [13] & $\begin{array}{l}\text { Mithilesh et } \\
\text { al. }\end{array}$ & $\begin{array}{l}\text { This paper was about } \\
\text { design and analysis of } \\
\text { connecting rod of different } \\
\text { materials. }\end{array}$ & $\begin{array}{l}\text { INVENTOR was } \\
\text { used to develop the } \\
\text { parametric model of } \\
\text { the connecting rod. } \\
\text { Analysis was done } \\
\text { with ANSYS 15.0. }\end{array}$ & $\begin{array}{l}\text { - Authors suggested Carbon } \\
\text { fiber can be used for } \\
\text { manufacturing connecting } \\
\text { rod. }\end{array}$ \\
\hline 14 & [14] & Lingaraj et al. & $\begin{array}{l}\text { To optimize size and shape } \\
\text { of connecting rod. }\end{array}$ & $\begin{array}{ll}- & \text { SOLID EDGE was } \\
\text { used to develop cad } \\
\text { model. } \\
\text { Analysis was } \\
\text { performed on } \\
\text { ANSYS. } \\
\end{array}$ & $\begin{array}{l}\text { - Web thickness of connecting } \\
\text { rod is reduced. } \\
\text { By shape optimization mass } \\
\text { of connecting rod is reduced } \\
\text { by } 4 \% .\end{array}$ \\
\hline 15 & [15] & Vijaya et al. & $\begin{array}{l}\text { In this paper connecting } \\
\text { rod of Yamaha Fz-s bike } \\
\text { replaced by other materials } \\
\text { like Chrome Steel and } \\
\text { Titanium for analysis. }\end{array}$ & $\begin{array}{ll}\text { - } & \text { Using CREO } \\
\text { PARAMETRIC 2.0, } \\
\text { connecting rod model } \\
\text { was developed. } \\
\text { Using ANSYS, FEA } \\
\text { was performed. } \\
\end{array}$ & $\begin{array}{l}\text { As per the authors, the peak } \\
\text { stress for titanium and } \\
\text { chrome steel materials is } \\
\text { within the acceptable stress } \\
\text { limit. }\end{array}$ \\
\hline 16 & [16] & Fanil et al. & $\begin{array}{l}\text { Investigating the stress } \\
\text { acting on connecting rod at } \\
\text { different loading } \\
\text { conditions. }\end{array}$ & $\begin{array}{l}\text { ANSYS was used to } \\
\text { build the cad model } \\
\text { of connecting rods. } \\
\text { Static structural } \\
\text { analysis was also } \\
\text { done by using } \\
\text { ANSYS. }\end{array}$ & $\begin{array}{l}\text { Authors concluded that both } \\
\text { the experimental and } \\
\text { numerical results were closer } \\
\text { to each other. }\end{array}$ \\
\hline 17 & [17] & Amit et al. & $\begin{array}{l}\text { Design and dynamic } \\
\text { analysis of connecting rod } \\
\text { using various materials like } \\
\text { 20CrMo, 30CrMo and } \\
\text { 42CrMo. }\end{array}$ & $\begin{array}{ll}- & \text { Cad model of } \\
\text { connecting rod was } \\
\text { developed by using } \\
\text { CATIA. } \\
\text { Dynamic analysis } \\
\text { was done with the } \\
\text { help of ANSYS 14.0. }\end{array}$ & $\begin{array}{l}\text { Authors concluded that } \\
\text { 42CrMo steel alloy requires } \\
\text { less material and less } \\
\text { dimensions compared with } \\
\text { 20CrMo and 30CrMo steel. }\end{array}$ \\
\hline 18 & [18] & $\begin{array}{l}\text { Ankit Gupta } \\
\text { and Mohd. } \\
\text { Nawajish }\end{array}$ & $\begin{array}{l}\text { In this work existed } \\
\text { connecting rod material is } \\
\text { replaced by other materials } \\
\text { to find best alternative. }\end{array}$ & $\begin{array}{l}\text { PRO-E } 4.0 \text { was used } \\
\text { to develop cad } \\
\text { model. } \\
\text { Analysis was } \\
\text { performed on } \\
\text { ANSYS 10.0. }\end{array}$ & $\begin{array}{l}\text { Authors suggested beryllium } \\
\text { alloy for connecting rod } \\
\text { production. }\end{array}$ \\
\hline 19 & [19] & $\begin{array}{l}\text { Naga } \\
\text { Malleshwara } \\
\text { Rao }\end{array}$ & $\begin{array}{l}\text { In this work author } \\
\text { explored weight reduction } \\
\text { possibilities in the } \\
\text { connecting rod by } \\
\text { examining various } \\
\text { materials. }\end{array}$ & $\begin{array}{ll}\text { - } & \text { The connecting rod } \\
\text { model was built with } \\
\text { PRO-E. } \\
\text { - } \\
\text { FEA was done by } \\
\text { using ANSYS. }\end{array}$ & $\begin{array}{l}\text { - We can find that the genetic } \\
\text { steel is showing less } \\
\text { deformation and stresses } \\
\text { than the other materials } \\
\text { which are considered during } \\
\text { the study. } \\
\end{array}$ \\
\hline 20 & [20] & Anusha et al. & $\begin{array}{l}\text { In this study connecting } \\
\text { rod of two different } \\
\text { materials analyzed. }\end{array}$ & $\begin{array}{l}\text { - The connecting rod } \\
\text { model was created } \\
\text { with PRO-E. } \\
\text { Static analysis was } \\
\text { performed on } \\
\text { ANSYS. }\end{array}$ & $\begin{array}{l}\text { - This study shows that the } \\
\text { stress is peak at small end of } \\
\text { the connecting rod. } \\
\text { Authors concluded that it is } \\
\text { better to use structural steel } \\
\text { as a connecting rod material } \\
\text { for long durability. }\end{array}$ \\
\hline
\end{tabular}

Published By:

Blue Eyes Intelligence Engineering 2370 \& Sciences Publication 
Design Considerations for Connecting Rod

\begin{tabular}{|c|c|c|c|c|c|}
\hline 21 & [21] & Abhinav et al. & $\begin{array}{l}\text { Static stress analysis of } \\
\text { connecting rod is } \\
\text { conducted to find } \\
\text { maximum stress point. }\end{array}$ & 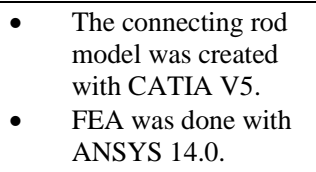 & $\begin{array}{l}\text { According to the authors, } \\
\text { area near the root of the } \\
\text { connecting rod's small end is } \\
\text { prone to failure. }\end{array}$ \\
\hline 22 & [22] & $\begin{array}{l}\text { Leela Krishna } \\
\text { and } \\
\text { VenuGopal }\end{array}$ & $\begin{array}{l}\text { This paper is about design } \\
\text { and analysis of connecting } \\
\text { rod. }\end{array}$ & $\begin{array}{l}\text { - } \quad \text { The connecting rod } \\
\text { model was built with } \\
\text { CATIA V5 R19. } \\
\text { - } \quad \text { ANSYS } 13.0 \text { was } \\
\text { used for Finite } \\
\text { element analysis. }\end{array}$ & $\begin{array}{l}\text { Forged steel connecting rod } \\
\text { showing better results when } \\
\text { compared with existing } \\
\text { carbon steel connecting rod. }\end{array}$ \\
\hline 23 & [23] & B. K. Roy & $\begin{array}{l}\text { Various designs of } \\
\text { connecting rod have been } \\
\text { analysed to suggest } \\
\text { optimum design } \\
\text { parameters. }\end{array}$ & $\begin{array}{l}\text { Using CATIA V5 } \\
\text { R19, the connecting } \\
\text { rod model was } \\
\text { created. } \\
\text { ANSYS } 12.0 \text { was } \\
\text { used for Finite } \\
\text { element analysis. }\end{array}$ & $\begin{array}{l}\text { - } \\
\text { Author concluded that } \\
\text { careful modification of } \\
\text { design parameters can give a } \\
\text { good design for connecting } \\
\text { rod. }\end{array}$ \\
\hline
\end{tabular}

Connecting rod's weight and design affects the performance of a vehicle. Changing the connecting rod material and changing the connecting rod design can result in variations in weight and stresses induced in it. As per the literature survey it is observed that weight reduction of connecting was obtained by

- Removing materials from certain regions where stress values are low [4], [24], [25].

- By modifying the connecting rod dimensions without altering the main dimensions [1], [6], [14], [23].

- Changing the material for manufacturing of connecting rod [2], [5], [11].

\section{MODELLING AND ANALYSIS \\ CASE - I}

\section{A. Modifying the connecting rod dimensions}

Model of the connecting rod was created with the help of INVENTOR software. Fig. 1 shows the actual model of connecting rod and Fig. 2 shows modified model of the connecting rod.

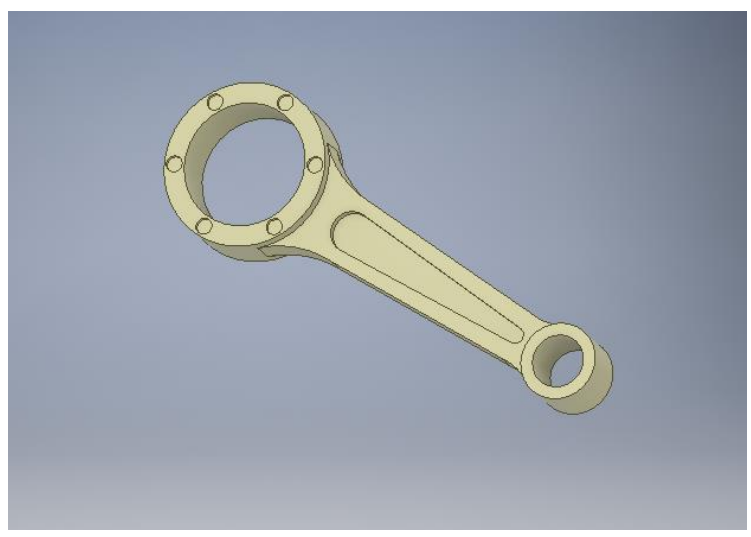

Fig. 1. Connecting rod model

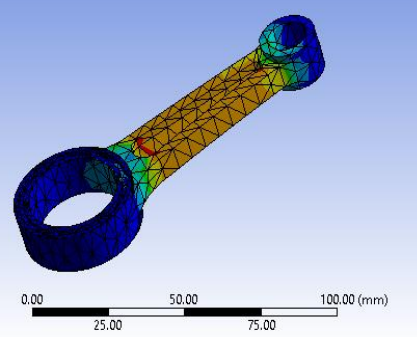

Fig. 3. Von-Mises stresses of Connecting rod

Table- II: Results of analysis of different connecting rod designs

\begin{tabular}{|c|c|c|c|c|}
\hline \multicolumn{5}{|c|}{$15000 \mathrm{~N}$ bearing load at small end and bid end is fixed } \\
\hline Material & Condition & $\begin{array}{l}\text { Von- } \\
\text { Mises } \\
\text { stress } \\
\text { (MPa) }\end{array}$ & Factor of safety & $\begin{array}{l}\text { Weight } \\
\text { (grams) }\end{array}$ \\
\hline \multirow{2}{*}{$\begin{array}{l}\text { Structural } \\
\text { Steel }\end{array}$} & $\begin{array}{c}\text { Before } \\
\text { Modifications }\end{array}$ & 224.5 & 1.1 & 127.6 \\
\hline & $\begin{array}{c}\text { After } \\
\text { Modifications }\end{array}$ & 247 & 1.1 & 116 \\
\hline
\end{tabular}




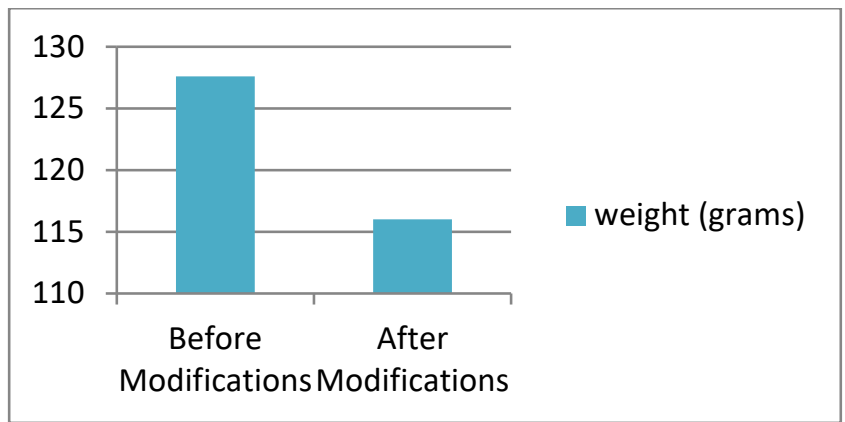

Fig. 4. Weight comparison

By observing Table- II and Fig. 4 we can say that modified design of connecting rod showing less weight than the actual design of connecting rod.

\section{CASE - II}

\section{A. Changing the material for connecting rod}

Static structural analysis of the connecting rod at $15 \mathrm{kN}$ bearing load with different materials was performed by using ANSYS. Materials used for analysis were given in the Table-III.

Table- III: Material Properties [1], [12], [29]

\begin{tabular}{|c|c|c|c|}
\hline Material & $\begin{array}{c}\text { Young's Modulus } \\
\text { (GPa) }\end{array}$ & $\begin{array}{c}\text { Poison's } \\
\text { Ratio }\end{array}$ & $\begin{array}{c}\text { Density } \\
\left(\mathbf{k g} / \mathbf{m}^{3} \text { ) }\right.\end{array}$ \\
\hline $\begin{array}{c}\text { Stainless } \\
\text { Steel }\end{array}$ & 193 & 0.31 & 7750 \\
\hline $\begin{array}{c}\text { Structural } \\
\text { Steel }\end{array}$ & 200 & 0.3 & 7850 \\
\hline Al 7075 & 71.7 & 0.33 & 2810 \\
\hline Ti-6Al-4V & 113.8 & 0.34 & 4430 \\
\hline
\end{tabular}

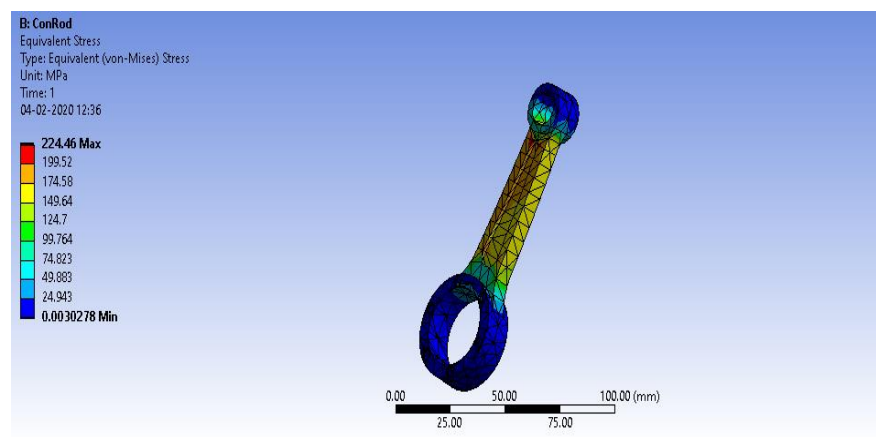

Fig. 5. Von-Mises stresses of Connecting rod

\section{B. Results Analysis of changing the connecting rod material}

Results for the various materials at $15000 \mathrm{~N}$ bearing load at small end of connecting rod are shown in Table-IV.

Table- IV: Result analysis of connecting rod of different materials

\begin{tabular}{|c|c|c|c|}
\hline \multicolumn{4}{|c|}{ 15000N bearing load at small end and bid end is fixed } \\
\hline Material & $\begin{array}{c}\text { Von-Mises stress } \\
\text { (MPa) }\end{array}$ & $\begin{array}{c}\text { Factor of } \\
\text { Safety }\end{array}$ & $\begin{array}{c}\text { Weight } \\
\text { (Grams) }\end{array}$ \\
\hline Structural Steel & 224.5 & 1.1 & 127.6 \\
\hline Stainless Steel & 224.5 & 0.9 & 126 \\
\hline
\end{tabular}

\begin{tabular}{|c|c|c|c|} 
Ti-6Al-4V & 224.5 & 3.9 & 72 \\
\hline Al 7075 & 225 & 2.6 & 45.7 \\
\hline
\end{tabular}

1) Weight comparison

By observing Table- IV and Fig. 6 we can say that, Al7075 material has lowest weight than other materials for same loading conditions.

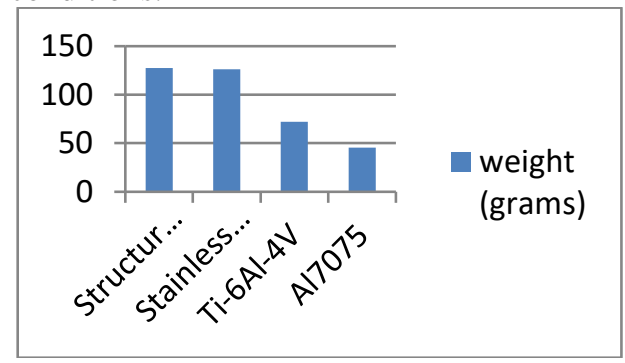

Fig. 6. Weight comparison

\section{2) Factor of safety comparison}

By observing Table- IV and Fig. 7 we can say that, Ti-6Al$4 \mathrm{~V}$ showing high factor of safety for the same loading conditions. So we can remove material from Ti-6Al-4V connecting rod for further decreasing weight of connecting rod.

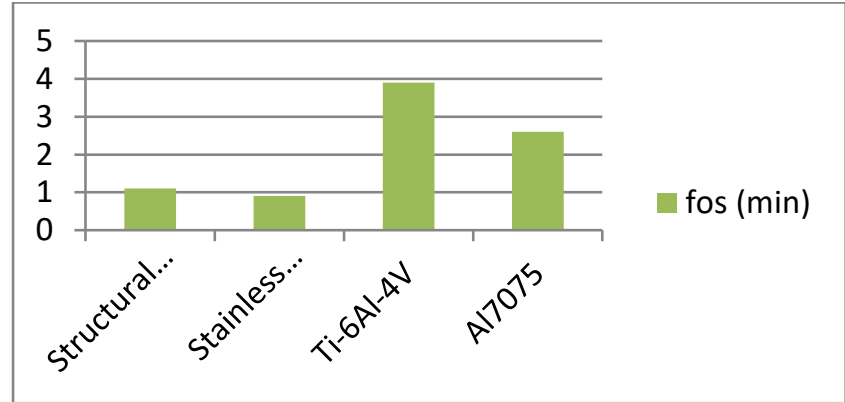

Fig. 7. Factor of Safety comparison

\section{CONCLUSIONS}

By observing results analysis tabulated in Table- II and Table- IV we can conclude that weight reduction of the connecting rod was obtained by,

- $\quad$ Removing material from big end of the connecting rod where stress values are low.

- From the Table- II we can say that the modified design of connecting rod showing less weight than the actual design of connecting rod for the same loading conditions. So we can use modified connecting rod instead of actual connecting rod.

- From the Table- IV we can say that, Al7075 material has lowest weight than other materials for the same loading conditions.

- From the Table- IV we can say that, Ti-6Al-4V showing highest factor of safety than other materials for the same loading conditions. So use $\mathrm{Al}$ alloy or $\mathrm{Ti}$ alloy for the manufacturing of connecting rod. 


\section{Design Considerations for Connecting Rod}

\section{REFERENCES}

1. Vinayak Chumbre, Vinayak Kallannavar, Anilkumar Shirahatti, Ratan Patil, Shirish M. Kerur, "Design and Comparative Analysis of Connecting Rod using Finite Element Analysis", International Journal for Research in Applied Science \& Engineering Technology (IJRASET),Volume 6, Issue IV, April 2018.

2. Nilam Pranjal Patil Dhande, Pundlik Patil, R.Y. Patil, " Analysis of Connecting Rod for Weight Reduction in Case of a CI engine”, IJEDR, Volume 6, Issue 1, 2018.

3. Adnan Ali Haider, Akash Kumar, AjinkyaChowdhury, Moin Khan, P. Suresh, " Design and Structural Analysis of Connecting Rod", International Research Journal of Engineering and Technology (IRJET), Volume: 05, Issue: 05, May-2018.

4. Vikas Singh, Sumit kr. Verma, Harish Chandra Ray, Vishal kr. Bharti, AbhineshBhaskar - "Design and Analysis of Connecting Rod forDifferent Material Using Ansys Workbench 16.2", IJRASET, Volume 5, Issue V, May 2017.

5. Magesh Kumar, Prof. Ankush K Biradar, "Design, Analysis and Optimization of Connecting Rod", International Journal of Innovative Research in Science, Engineering and Technology, Volume 6, Special Issue 11, May 2017.

6. Dipalee S. Bedse, "Design Evaluation of Connecting Rod", International Journal of Recent Engineering Research and Development, Volume 02, Issue 07,July 2017, PP. 203-213.

7. Ganta Krishnarjuna Reddy, Badde Naik Vadithe, "Design and Analysis ofConnecting Rod", IJRAET ,Volume 6, Issue 1, MAY 2017.

8. Dr. N. A. Wankhade, SuchitaIngale, "Review on Design and Analysis of Connecting Rod Using DifferentMaterial", International Journal of Engineering Science and Computing, Volume 7, May 2017.

9. Nilam P. Patil, Pundlik N. Patil, Raghunath Y. Patil, “ Design Analysis of Connecting Rod for Weight Reduction in Case of a CI Engine - A Review", International Journal of Engineering Sciences \& Research Technology, September- 2017.

10. Mansi S. Satbhai, P.S. Talmale, "Review on Design and Analysis of Two Wheeler Connecting Rod", International Research Journal of Engineering and Technology, Volume: 04, Issue: 09, Sep -2017.

11. SathishWable, Dattatray S. Galhe, "Analysis of Stresses Induced in Connecting Rod of Two Wheeler Engine", IJARIIE, Volume2, Issue3, 2016.

12. Harshit Mishra, Prof. KuldeepNarwat, "Static and Modal Analysis of Connecting Rod",

13. Mithilesh K Lade, Ritesh P Harode, DeepaliBankar Lade, "Static Load Analysis of Carbon Fiber Connecting Rod",International Journal of Research in Advent Technology, Volume 3, No.9, September 2015.

14. Lingaraj K. Ritti, Pavan Kumar, AmbarishM ,“ Size and Shape Optimization of aTwo Wheeler Connecting Rod byStructural Analysis", International Journal of Analytical, Experimental and Finite Element Analysis, Volume 2, Issue 1, March 2015.

15. S.Vijaya Kumar, S.K. Thenadayaal, V.P. Vasanth, V. Vasanthakumar, "Design and Analysis of Two WheelerConnecting Rod", International Journal of Innovative Research in Science,Engineering and Technology,Volume 4, Special Issue 6, May 2015.

16. Fanil Desai, KiranKumarJagtap, AbhijeetDeshpande, “ Numerical andExperimental Analysis of Connecting Rod",International Journal of Emerging Engineering Research and Technology,Volume 2, Issue 4, July 2014, PP 242-249.

17. Amit Kumar, Bhingole P.P, Dinesh Kumar, "Dynamic Analysis of Bajaj Pulsar 150cc Connecting RodUsing ANSYS 14.0”,Asian Journal of Engineering and Applied Technology ,Vol. 3 No. 2, 2014, pp.19-24.

18. 18. Ankit Gupta, Mohd.Nawajish,"Design and Analysis of Two Wheeler Connecting Rod Using Different Materials",IJARSE, Volume 3, Special Issue 01, September 2014.

19. G.NagaMalleshwara Rao, "Design Optimization and Analysis of a Connecting Rod using ANSYS”, IJSR, Volume 2, Issue 7, July 2013.

20. B.Anusha, Dr.C.VijayaBhaskarReddy, "Comparison Of Materials For Two-WheelerConnecting Rod Using Ansys", International Journal of Engineering Trends and Technology, Volume 4, Issue 9, Sep 2013.

21. Abhinav Gautam,K PriyaAjit, "Static Stress Analysis of Connecting Rod Using Finite ElementApproach”, IOSR Journal of Mechanical and Civil Engineering, Volume 10, Issue 1, Nov. - Dec. 2013, PP 47-5.

22. Leela Krishna Vegi, VenuGopalVegi, "Design And Analysis of Connecting RodUsing Forged steel”, International Journal of Scientific \& Engineering Research, Volume 4, Issue 6, June-2013.

23. Dr. B. K. Roy, "Design Analysis and Optimization of VariousParameters of Connecting Rod using CAESoftwares", IJNIET, Volume 1, Issue 1, October 2012.

24. P.S. Rao, P.K. Jain, D.K. Dwivedi, "ELECTRO CHEMICAL HONING (ECH) OF EXTERNAL CYLINDRICAL SURFACES- AN INNOVATIVE STEP”, DAAAM INTERNATIONAL VIENNA
PUBLISHERS, 09 CHAPTER, DAAAM International Scientific Book (2015), 097-116.

25. P.S. Rao, P.K. Jain, D.K. Dwivedi, "ELECTRO CHEMICAL HONING (ECH)- A NEW PARADIGM IN HYBRID MACHINING PROCESS", DAAAM INTERNATIONAL VIENNA PUBLISHERS, 26 CHAPTER, DAAAM International Scientific Book (2016), 287306.

26. P.S. Rao, P.K. Jain, D.K. Dwivedi, "Electro Chemical Honing (ECH) of External Cylindrical Surfaces of Titanium Alloy", Elsevier Publishers, J. of Procedia engineering, 100 (2015), 936-945.

27. P.Sudhakar Rao, P.K. Jain, D.K. Dwivedi, "Precision Finishing of External Cylindrical Surfaces of EN8 Steel by Electro Chemical Honing (ECH) Process using OFAT Technique", Elsevier Publishers, J. of Materials Today Proceedings, 2 (2015), 3220-3229.

28. V. B. Bhandari,'Design of Machine Elements"

29. http://www.matweb.com

30. https://www.enginebuildermag.com/2007/04/performance-connectingrods/

\section{AUTHORS PROFILE}

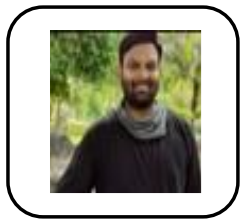

B. Sriharsha, completed his Bachelor of Technology (Mechanical Engineering) from Dr. VRKCET affiliated to JNTU University. At present, he is pursuing Master of Engineering (Manufacturing Technology) from NITTTR, Chandigarh. His research areas are nonconventional machining, CAD/CAM, modeling and simulation, and automation.

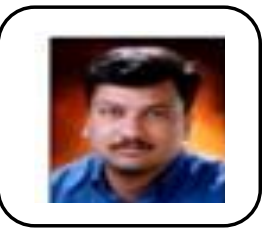

Dr. P. Sudhakar Rao, Assistant Professor in Mechanical Engineering Department, NITTTR, Chandigarh. He completed his Ph.D. from IIT Roorkee. Key areas of research interests include Manufacturing Technology, Engineering Design, Non-Conventional Machining, CAD/CAM/CIM, Engineering Materials, and RPT/RE. 